\title{
Planktonic foraminiferal response to Middle Miocene cooling in the Southern Ocean (ODP Site 747, Kerguelen Plateau)
}

\author{
Wojciech Majewski \\ Acta Palaeontologica Polonica 55 (3), 2010: 541-560 doi: http://dx.doi.org/10.4202/app.2009.0088
}

The response of planktonic foraminifera to changing oceanographic conditions during Middle Miocene Climate Transition (MMCT) 14 million years ago (Ma) at ODP Site 747 (Kergeulen Plateau) is investigated. Faunal changes are presented in the background of sea surface temperature (SST) estimates and multi-taxon $\delta^{18} \mathrm{O}$ and ${ }^{\circ} 13 \mathrm{C}$ data presented in other studies. Four faunal transitions are distinguished between 15.0 and $12.2 \mathrm{Ma}$. The first two affected only a limited number of taxa, and do not lead to large-scale assemblage reorganizations. They are only minor assemblage changeswithin the pre-MMCT fauna. The first (14.5-14.4 Ma) is marked by a reduction in the Globorotalia zealandica plexus in favor of the Globorotalia praescitula plexus, coupled with the first signs of increased seasonality. The second (14.3-14.2Ma) is characterized by recovery and diversification of the G. zealandica plexus and an increase in Turborotalita quinqueloba in response to further enhanced seasonality. The third faunal transition across the Middle Miocene Shift (MMS) in $\delta^{18} \mathrm{O}(13.9-13.8 \mathrm{Ma})$ affects almost all planktonic foraminifera, leading to dismembering of the pre-MMCT assemblage. These changes were triggered by the SST drop by $\sim 7^{\circ}$ $\mathrm{C}$, followed by reduced sea-surface salinity following the MMS, which favored the opportunistic Neogloboquadrina continuosa. Its dominance spans the transitional period (13.8-13.2Ma), during which several planktonic foraminiferal events gradually shaped the post-MMCT assemblage. The fourth faunal threshold took place during the hiatus in the ODP Hole 747A record spanning 13.2-12.5Ma. It is expressed by the establishment of an assemblage dominated by Globorotalia praescitula and Globigerina bulloides in association with diminishing of the low-salinity surface layer. The two dominant taxa exhibit well-definedmorphologies,much different from their earlier relatives. The microperforate foraminifera show relatively few morphological changes, probably due to their morphological conservatism. Their changes are thought to herald the large foraminiferal transformations, especially in case of the third and fourth faunal transition thresholds.

Key words: planktonic foraminifera, climate change, Middle Miocene, Kerguelen Plateau, Southern Ocean.

Wojciech Majewski [wmaj@twarda.pan.pl], Instytut Paleobiologii PAN, ul. Twarda 51/55, PL-00-818 Warszawa, Poland 
Attribution License (for details please see creativecommons.org), which permits unrestricted use, distribution, and reproduction in any medium, provided the original author and source are credited.

PoFif Full text $(902.4 \mathrm{kB})$ 